\title{
SISTEM Open Building DALAM BANGUNAN HUNIAN
}

Open Building System In Residential Building

\author{
Aldhi Nugraha Anantama, Ikaputra \\ Program Magister Arsitektur, Departemen Arsitektur dan Perancangan, Universitas Gadjah Mada \\ Jl. Grafika no. 2, Kampus UGM, Yogyakarta 55281, Indonesia \\ anantama.aldhi@mail.ugm.ac.id
}

\begin{abstract}
Abstrak
Konsep sistem Open Building yang diutarakan oleh Habraken pada tahun 1961, menggagas mengenai pemisahan struktur (support) dengan interior \& non-struktural (infill), sehingga antara satu dan lainnya tidak saling bergantung jika ada perubahan dalam bangunan. Penelitian ini berfokus membahas dasar-dasar dari teori Open Building dan bagaimana hubungannya dengan arsitektur yang berkelanjutan. Selain itu, untuk mengetahui kelebihan juga kekurangan dari sistem tersebut. Metode yang digunakan pada penelitian ini adalah studi literatur yang menggunakan data sekunder dari berbagai tulisan serta artikel yang membahas serta mendukung pembahasan mengenai Open Building. Dari hasil akhir yang didapatkan, beberapa pernyataan atau penelitian sebelumnya memang mendukung Open Building sebagai suatu sistem yang mendukung arsitektur yang berkelanjutan dengan kemampuan beradaptasinya, namun tetap diperlukan dukungan dari instansi pemerintah yang terkait, dan juga pengenalan lebih lanjut kepada masyarakat umum.
\end{abstract}

Kata kunci: adaptasi, berkelanjutan, hunian, Open Building, system.

\begin{abstract}
The concept of an Open Building system, expressed by Habraken in 1961, initiated the separation of the structure (support) from the interior \& non-structural (infill), so that they do not depend on each other if there are changes in the building. This study focuses on discussing the basics of Open Building theory and how it relates to sustainable architecture. In addition, to find out the advantages and disadvantages of the system. The method used in this research is a literature study that uses secondary data from various writings and articles that discuss and support the discussion of Open Building. From the final results obtained, several statements or previous studies do support Open Building as a system that supports sustainable architecture with its adaptability, but support from relevant government agencies is still needed, as well as further introduction to the general public.
\end{abstract}

Keywords: adaptation, sustainable, residential, Open Building, system.

\section{Pendahuluan}

\section{Munculnya Open Building}

Asal mula munculnya konsep sistem Open Building diungkapkan dalam tulisan Cuperus (2017) berasal dari salah satu kutipan pada tahun 1961 oleh John Habraken, yaitu: 'We should not to forecast what will happen, but try to make provisions for the unforeseen'. Kutipan tersebut jika diartikan ke dalam bahasa
Indonesia kurang lebih berbunyi: 'Kita sebaiknya tidak meramalkan apa yang akan terjadi, tetapi mencoba mempersiapkan hal yang tidak terduga'. Kutipan tersebut jika ditarik garis ke belakang, merujuk pada permasalahan perumahan pada abad ke-20 di mana meningkatnya produksi hunian berskala besar yang dapat mengakomodasi penduduk dalam jumlah banyak. Di satu sisi hunian masal tersebut dianggap efektif 
dalam mengurangi biaya pembangunan satuan tiap unitnya, namun pada sisi yang lainnya hunian masal yang 'statis' tersebut tidak mampu untuk beradaptasi dengan mudah mengikuti kebutuhan dari user penghuni atau dalam kasus ini berperan sekaligus sebagai kostumer hunian masal tersebut (Oorschort dkk, 2011).

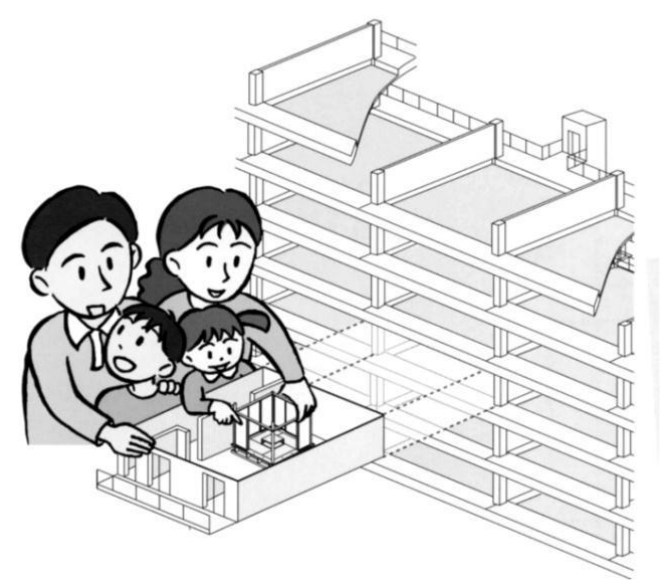

\section{Gambar 1. Support, Infill, dan Partisipasi Penghuni} (Sumber: Setien, 2015)

Habraken dengan konsep sistem Open Building ini memiliki gagasan untuk memisahkan 'support' sebagai struktur bangunan dengan 'infill' sebagai elemen non-struktural, lalu memberikan wewenang dan kemampuan kepada pengguna bangunan dalam pertimbangan perancangan dan pengambilan keputusan terkait (Geldermans dkk, 2019). Secara umum, pengaturan kostumisasi rancangan Open Building termasuk komponen interior, eksterior, juga penataan ruang yang juga menentukan area keseluruhan dari sebuah hunian (Hofman dalam Oorschot dkk, 2011).

\section{Kelebihan \& Urgensi Open Building}

Dengan berbagai kebaruan dari sistem yang ditawarkan melalui Open Building, Habraken (2002) merincikan beberapa kelebihan atau efisiensi dari Open Building, sebagai berikut:

\section{Komponen Baru}

Pemisahan yang jelas antara support dan infill menciptakan kemungkinan untuk merancang dan memproduksi komponen infill dalam jumlah yang besar dan dapat dijual ke pasaran. (Habraken, 2002)

2. Hemat Waktu dan Ongkos Pekerja Instalasi infill dan support yang terpisah dapat menghemat waktu dan jumlah pekerja di lapangan (Habraken, 2002). Tahap support dan infill bisa dikerjakan dalam waktu yang bersamaan namun pada lokasi yang berbeda. Sebagaimana support dikerjakan langsung di lapangan, pekerjaan infill sudah bisa mulai dikerjakan secara fabrikasi. Sehingga saat support sudah selesai dikonstruksi, infill yang setengah jadi dapat langsung lanjut dikonstruksikan di lapangan.

3. Sistem yang dapat berkembang

Karena infill adalah sistem yang terpisah, maka ia dapat ikut berkembang seiring waktu (Habraken, 2002). Sebagai sistem yang dapat dibongkar-pasang dan bersifat tidak bergantung kepada support, infill memiliki fleksibilitasnya sendiri. Jika ada pengembangan teknologi, infill dpaat berjalan dan berkembang sendiri tanpa banyak pengaruh dari support atau elemen infill lainnya.

4. Variatif

Sistem ini dapat memiliki variasi yang beragam dari segi kualitas dan harga (Habraken, 2002). Sistem Open Building yang memungkinkan bongkar-pasang pada bagian infill menciptakan variasi yang sangat banyak. Bagian infill dapat di kombinasikan satu sama lain dan menciptakan variasi material, gaya, hingga variasi harga yang ingin dipakai, kembali lagi ke kebutuhan dan keinginan sang pengguna itu sendiri.

5. Penggunaan Secara Luas

Pre-fabrikasi sistem ini dapat diterapkan tidak kepada satu bangunan saja (Habraken, 2002). Berbeda dengan bangunan pre- 
fabrikasi pada umumnya yang elemen konstruksinya hanya bisa dipakai di satu bangunan tertentu saja, Open Building menawarkan konsep di mana elemen infill dapat dipakai di banyak bangunan secara masal namun tetap mempertimbangkan support yang sesuai. Dengan ini elemen infill dapat dijual secara bebas dan meluas.

6. Keunikan Setiap Ruang

Walau dasar support sama, denahnya dapat berbeda-beda (Habraken, 2002). Seperti yang dijelaskan sebelumnya, support dapat dibuat berulang-ulang secara repetitif namun keputusan perancangan infill tetap berpusat kepada pengguna bangunan tersebut.

7. Berkelanjutan

Masing-masing unit dapat berubah dan berkembang seiring waktu dan kebutuhan penggunanya (Habraken, 2002). Kembali ke konsep dasar Open Building sebagai sistem yang mendukung keberlanjutan dengan memisahkan support dan infill, sehingga jika kebutuhan dan kemauan pengguna berubah, tetap dapat disesuaikan dengan memodifikasi infill tanpa mengganggu support.

\section{Metode}

Fokus dari tulisan ini adalah membahas tentang dasar dari konsep Open Building dan hubungannya dengan arsitektur berkelanjutan serta mengetahui kemungkinan dan batasan dari konsep ini. Metode yang digunakan pada tulisan ini adalah studi literatur yang membahas mengenai teori Open Building berdasar data sekunder yang berupa tulisan-tulisan sebelumnya yang mencakup dan mendukung pembahasan mengenai Open Building.

\section{Kajian Teori}

\section{Definisi Open Building}

Li (2017), menerangkan bahwa Konsep Open Building pertama kali dipaparkan oleh Habraken dalam bukunya Supports: An Alternative to Mass Housing (1962) yang berisi mengenai efek-efek yang lahir dari konstruksi perumahan massal di Belanda. Efek-efek tersebut, seperti: sifat yang monoton, kurangnya partisipasi penghuni, dan kegagalan mendapatkan manfaat dari sistem pembangunan industrial. Habraken merumuskan alternatif yang cukup radikal, yaitu: sebuah gagasan konsep yang memisahkan 'support' atau dasar (struktur) bangunan dari 'infill' atau interior (dan non struktural) pada konstruksi dan perancangan perumahan. Kemudian, Open Building didasarkan pada keyakinan bahwa varisasi dan keberagaman dapat menghasilkan hunian massal yang lebih baik, dalam segi produktifitas dan efisiensi.

Selain itu juga banyak pandangan mengenai Open Building menurut beberapa sumber sebagai berikut:

1. Nascimento

Open Building adalah pendekatan perancangan yang akan meningkatkan variasi, fleksibelitas, dan kualitas dari ruang. Konsep ini akan menjamin gagasan dan personalisasi hidup dari penghuninya (Nascimento, 2012).

2. Ian Kilpatrick

Open Building adalah konsep yang memiliki pandangan dalam menciptakan ruang yang dapat berubah seiring dengan penggunanya, konsep ini mendefinisikan kembali bagaimana perancang berpikir tentang perumahan (Kilpatrick, 2015).

3. Guopeng Li

Open Building adalah pendekatan yang penting dan sistematik untuk merancang dan konstruksi untuk dapat beradaptasi dipandang dari segi menggabungkan komponen bangunan sedemikian rupa untuk memberikan 
kebebasan yang optimal pada layout dan instalasinya ( $\mathrm{Li}, 2015)$.

4. Israel Nagore Setien

Prinsip Open Building mendorong arsitektur yang terbuka (fleksibel) dan dapat beradaptasi dengan tujuan untuk memenuhi keragaman dan perubahan kebutuhan dari pengguna seiring waktu berjalan (Setien, 2015).

5. Johannes A.W.H. Van Oorschot

Tujuan utama dari Open Building adalah untuk mencapai individualitas diantara bagian banguan, sehingga dapat diciptakan bangunan yang bisa beradaptasi dengan kebutuhan baru dari penghuninya (Oorschot, 2011).

6. Stephen Kendall

Open Building adalah prinsip di mana bangunan dapat beradaptasi dari waktu ke waktu dalam perubahan fungsi dan pereferensi dengan konflik (permasalahan) yang minimal. Bangunan seperti itu akan stabil, juga akan mengakomodasi teknologi yang baru, dan juga memungkinkan perubahan dalam organisasi kerja, gaya hidup penghuni, dan dalam bentuk rumah tangga yang penghuni tadi bentuk sendiri. Jika bangunan dibangun untuk kebutuhan saat ini dan perubahannya di masa depan, bangunan tersebut dapat mewakili sustainable (berkelanjutan) dalam arah yang luas. (Kendall, 1999).

Berdasar beberapa definisi di atas, Open Building dapat disimpulkan sebagai: Sebuah prinsip yang mengakomodasi suatu sistem yang dapat memberikan kemampuan pada bangunan untuk berubah dan beradaptasi sesuai dengan kebutuhannya. Selain itu, juga adanya preferensi dari penggunanya dengan memisahkan bagian 'Support' (struktural) dan 'Infill' (non-struktural). Hal itu dilakukan sehingga untuk meminimalisir konflik dalam transformasinya dan menjadikannya sebagai bangunan yang berkelanjutan.

\section{Prinsip Awal Open Building}

Mengutip dari Setien (2015), prinsip Open Building pertama kali ditulis oleh Habraken pada bukunya 'De Dragers en de Mensen' pada tahun 1962, buku tersebut berisi pergeseran paradigma mengenai bagaimana memahami housing project (proyek pembangunan hunian). Secara lebih lanjut, buku ini juga membahas bagaimana bangunan tempat tinggal dirancang, dikelola, dibangun, dan pada akhirnya ditempati. Gagasan Open Building tersebut pada saat ini masih relevan dengan tiga isu utama masalah perancangan hunian di abad ke-21 yaitu : hunian harus beragam, hunian harus dapat menerima perubahan dan transformasi, dan hunian harus menggabungkan penghuni sebagai bagian dari proses pengambilan keputusan. Secara lebih rinci, Setien (2015) memaparkan ketiga prinsip dasar tersebut:

1. Pemahaman bahwa lingkungan terbangun sebagai lingkungan dinamis, lingkungan yang tidak pernah berhenti berubah sepanjang waktu. Lingkungan terbangun - bangunan dan ekstensi kota- adalah organisme hidup yang dikendalikan oleh peraturan dan prinsip, sehingga perkembangannya susah untuk dikontrol dan diprediksi.

Prinsip Open Building berdasar dari persepsi lingkungan terbangun sebagai struktur yang memiliki beberapa lapisan, di mana lima sistem fisik utamanya dapat dikenali. Pada kota, kita dapat mengidentifikasi:
a. Urban Structure
b. Urban Tissue
c. Buildings
d. Infill Components
e. Furniture

Setiap sistem memiliki rentang waktu hidup yang berbeda dan tingkatan kontrol yang harus berkaitan satu sama lainnya. Lingkungan terbangun 'sustainable' (berkelanjutan) berada pada tahapan di mana tiap sistem dapat 
bertransformasi dengan sendirinya dan secara bagian per bagian. Ini adalah tujuan dari Open Building. Secara singkat, Open Building mengusulkan agar arsitektur dapat memisahkan bagian yang dapat diubah dengan bagian yang permanen.

2. Prinsip kedua Open Building berdasar dari ide bahwa jika ingin menciptakan lingkungan terbangun menjadi lingkungan yang sehat dan berkelanjutan, pengguna dan komunitas perlu menjadi bagian dari proses perancangannya. Hingga abad ke-20, orang-orang merancang bahkan membangun hunian mereka dalam hubungan atau kolaborasi yang dekat dengan tukang atau pekerja. Namun ‘Natural Relation' (relasi alami) diantara user (pengguna) dan lingkungan terbangun telah runtuh dengan pergerakan industri modern hunian massal, serta kemajuan 'professionalization',

'institutionalisation', dan 'legislation' dari perancangan dan prosedur pembangunan dalam abad terakhir.

Munculnya agen baru dalam proses, seperti banker, politisi, pengacara, kontraktor, dan konsultan khusus melahirkan sistem pekerjaan kolaboratif yang baru dan kompleks, namun tidak memberikan bagian kepada pengguna dalam proses pengambilan keputusan. Pada intinya: jika hanya pengembang pribadi, profesional, atau pihak berwewenang saja yang terlibat dalam pembangunan kota, maka hasilnya adalah keseragaman, di mana penghuni tidak diikutsertakan dan tidak dapat berpartisipasi dalam proses pengambilan keputusan yang berhubungan dengan lingkungan hidup mereka.

3. Prinsip ketiga adalah efek dari dua prinsip sebelumnya dan berkaitan dengan isu teknis. Sifat dari kedua sistem yaitu perbedaan rentang waktu hidup pada bangunan (infrastruktur dan infill), dan kebutuhan mengenai perlengkapan untuk unit yang dapat dipisahkan memberikan peluang untuk sub-sektor baru yang mengakomodasi elemen yang dapat dibongkar-pasang. Peluang pasar baru ini berbasis dari komponen 'open-industrializatioan' yang dapat memberikan kemampuan kepada penghuni untuk memilih beberapa pilihan pengaturan dari peforma, kualitas, dan biaya yang ditawarkan oleh industri bangunan.

Dengan konteks masyarakat yang kian berubah mengikuti perkembangan teknologi, setiap elemen pada bangunan diharapkan dapat berubah (mengikuti kebutuhan). Singkatnya, Open Building adalah sebuah bentuk pemahaman mengenai bangunan sebagai gabungan dari beberapa sistem yang berdiri sendiri, sehingga suatu sistem dapat diganti atau diubah dengan tanpa memengaruhi sistem lainnya.

\section{Tahapan Perancangan Open Building}

1. Fase Satu

Pekerjaan arsitektur pada fase pertama dibatasi hingga bagian pekerjaan standar saja. Hasil akhir dari tahap pertama umumnya berupa Open Plan atau Denah Terbuka, yaitu struktur dan pelat lantai kosong yang memungkinkan pengguna untuk mengalokasikan partisi, finishing, dan peralatan lainnya sesuai dengan kebutuhan dan situasi ekonominya. Dalam kata lain, fase pertama melibatkan support sebagai fokus utamanya. Pada fase ini Support dapat dibuat berulang-ulang dan repetisi dalam jumlah banyak bahkan dalam satu bangunan yang sama. 


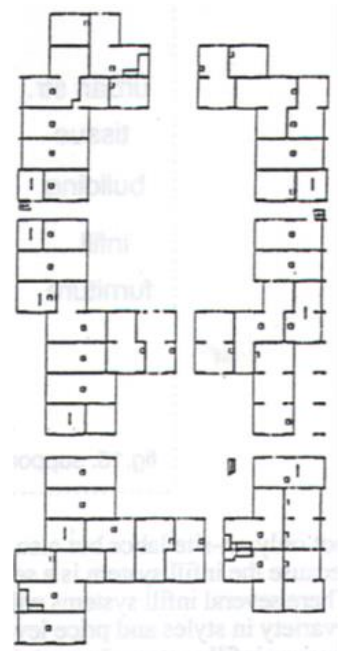

\section{Gambar 2 Contoh Hasil dari Fase Satu}

(Sumber: Habraken (2002))

\section{Fase Dua}

Pada fase kedua, support yang telah dikonstruksikan pada fase pertama akan mulai diisi dengan infill. Pengguna memiliki peran besar dalam pengambilan keputusan dalam perancangan dan konstruksi infill, sehingga hasil dari infill tentunya akan berbeda-beda mengacu kepada setiap penggunanya. Walaupun memiliki support yang seragam, namun infill dengan sendirinya memiliki variasi yang beragam dan unik antar satu dengan lainnya. Fase kedua ini dapat diulangi lagi di masa yang akan datang setiap kali kebutuhan dari pengguna yang ikut berubah-ubah.

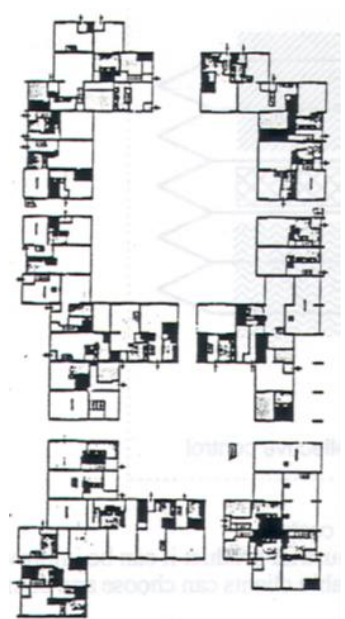

Gambar 3. Contoh Hasil dari Fase Dua (Sumber: Habraken (2002))

\section{Tingkatan Pengambilan Keputusan dalam Open Building}

Dalam gagasan 'mempersiapkan hal yang tidak terduga', konsep 'level' (tingkatan) menjadi solusinya. Tiga level dalam pengambilan keputusan dibagi menjadi Tissue, Support, dan Infill. Tiap level tersebut dipisahkan namun tetap saling berkordinasi antara satu sama lain. Habraken dalam Cuperus (2017) memaparkan level tersebut melalui Diagram 1.

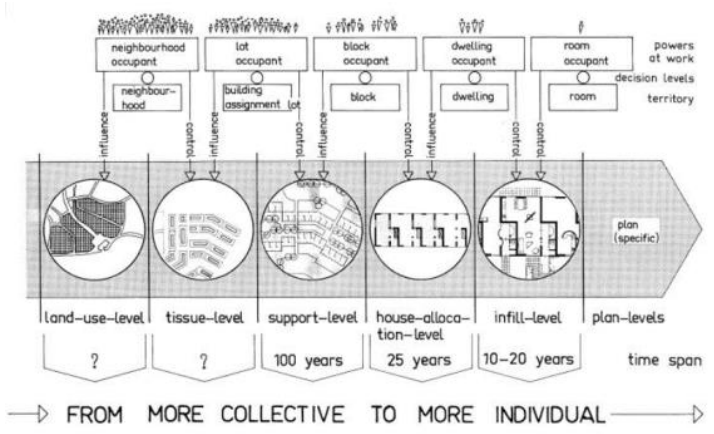

\section{Diagram 1. Tingkatan Pengambilan Keputusan dalam Open Building Sumber: Cuperus (2017)}

Pada sistem ini, level (tingkatan) yang lebih luas mengakomodasi dan membatasi tingkatan yang lebih rendah, dan sebaliknya tingkatan yang lebih rendah menentukan persyaratan dari tinggkatan yang lebih tinggi. Setiap tingkatan terdapat 'ultimate costumer' (kostumer utama), contohnya seperti konsumen pada tingkatan 'infill', developer pada tingkatan 'support', dan pemerintah kota pada tingkatan 'tissue' (Cuperus, 2017).

Pada Unesco Regional Seminar, Habraken (2002) menjelaskan lebih lanjut mengenai konsep 'level', dimana konsep tersebut pada hakikatnya adalah bukan konsep yang benar-benar baru. Contoh sederhana, pada umumnya urban designer bekerja pada level (tingkatan) yang 'lebih tinggi' dari pada arsitek. Hal tersebut juga berlaku dalam sistem level pada open building, sebagai perumpamaan, urban designer bertugas merancang jalur jalan, pembagian blok, dan hal lainnya yang berhubungan dengan kawasan. Kemudian pada lokasi tersebut, arsitek memiliki tugas untuk merancang bangunan mengikuti 
konteks kawasan yang dirancang oleh urban designer, dimana arsitek harus menghormati peraturan dan tatanan kawasannya. Dalam konteks tersebut, arsitek dapat bebas berkreasi, dapat mengganti rancangan bangunannya dengan berbagai macam bentuk yang dikehendaki.

Namun, jika jalur jalan (pada lingkup ini adalah kawasan) harus diubah, maka bangunan yang ada di dalamnya harus ikut menyesuaikan. Urban designer tidak bisa bertindak tanpa memengaruhi rancangan arsitek di dalamnya. Relasi ini memang tidak seimbag, perubahan pada level bangunan tidak memengaruhi level yang lebih tinggi yaitu kawasan, namun sebaliknya, perubahan pada level kawasan memengaruhi level bangunan di bawahnya (Habraken, 2002).

Pada kasus open building dengan level hunian, pembagian kontrol dapat diskemakan melalui Diagram 2. Terlihat pada level urban structure, tissue, dan support merupakan level yang dikontrol oleh (tenaga) profesional, dalam kasus ini adalah urban designer dan juga arsitek. Sedangkan pada level infill dan furniture dikontrol langsung oleh user (pengguna) dan dapat diubah serta dikembangkan kapan saja sesuai dari keinginan dan kebutuhan pengguna.

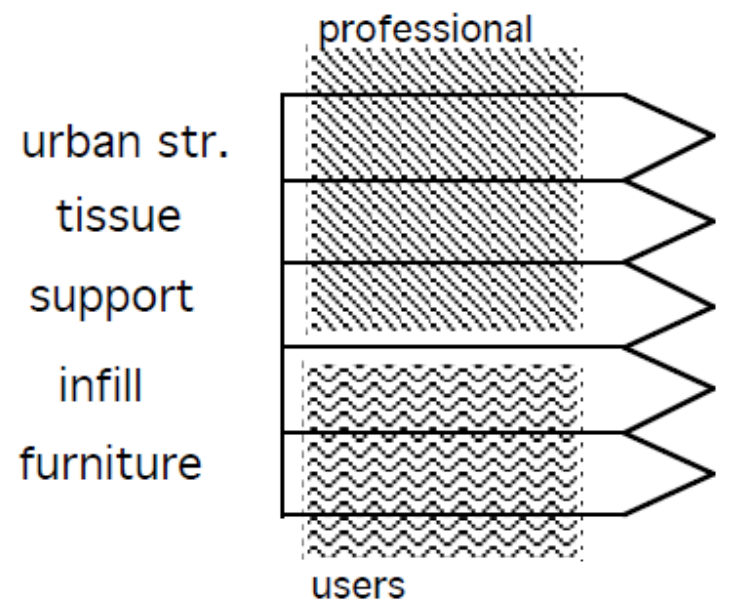

\section{Diagram 2. Pembagian Kontrol Open Building pada Level Hunian (Sumber: Habraken (2002))}

Namun terdapat juga skenario lain di mana para pengguna secara kolektif ikut mengatur support bangunan, contohnya seperti kondominium, maka skema yang lebih cocok adalah Diagram 3. Pada skenario ini, tenaga profesional tetap bekerja pada lingkup level Urban Structure, Tissue, dan Support. Yang menjadi pembeda adalah pengguna yang ikut berpartisipasi dalam perancangan support, sehingga pengguna dapat mengatur huniannya lebih awal dan secara lebih intim.

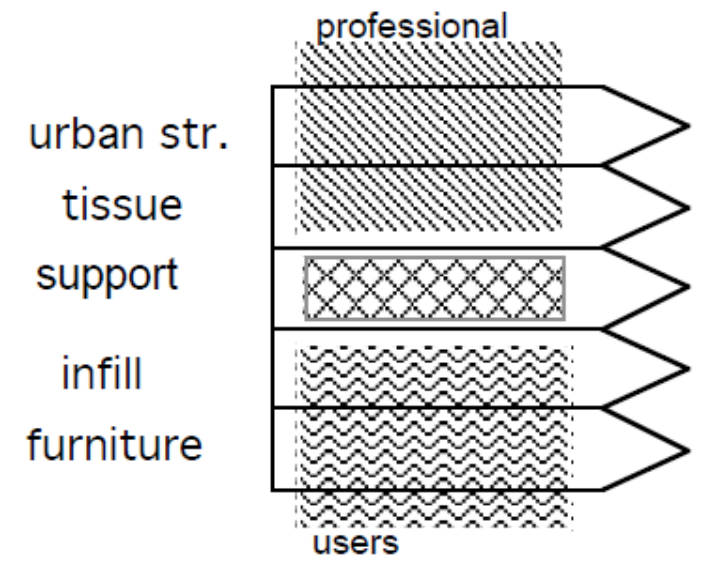

Diagram 3. Pembagian Kontrol Open Building pada Level Hunian Khusus (Kondominium)

(Sumber: Habraken (2002))

\section{Studi Preseden - Solid Oud West,} Amsterdam

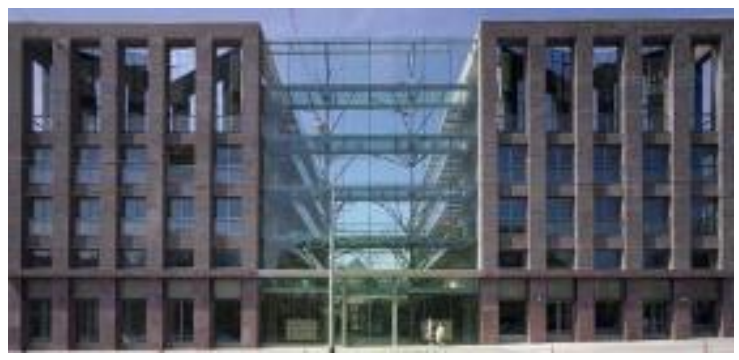

\section{Gambar 4. Solid Oud West (Sumber: Archdaily (2002))}

Perusahaan pemrumahan Stadgenoot, sebagai organisasi swasta nirlaba yang memiliki hubungan dengan otoritas lokal, menggagas rancangan dan konstruksi bangunan "Solids" di Amsterdam pada tahun 2010 (archdaily). Berdasarkan Stadgenoot, Solid adalah bangunan berkelanjutan yang dikonstruksikan untuk dapat bertahan setidaknya 200 tahun, dan dirancang tanpa 'tujuan' yang telah ditentukan sebelumnya; 
nyatanya, bangunan ini harus dapat mengakomodasi berbagai macam kegunaan. Solids terinspirasi oleh bangunan pabrik New York pada abad ke19 dengan fasad baja yang monumental dan kokoh serta masih digunakan hingga sekarang.

Pendekatan yang digunakan Solid berdasarkan konsep: infrastruktur dasar dirancang dan dihasilkan sebagai sebuah cangkang, siap untuk mengakomodasi berbagai penggantian fit-out yang ditentukan pengguna seiring waktu. Konsep ini memungkinkan ruang yang ada dapat berfungsi dngan berbagai tujuan: hidup, bekerja, budaya, dan kombinasi lainnya.

Stadgenoot menyelesaikan konstruksi Solid pertama pada April 2011, bangunan ini disebut Furore. Furore terletak di Oud West district, daerah pusat dari Amsterdam. Proses perancangan Furore dibagi menjadi dua tahap:

1. Tahap Pertama

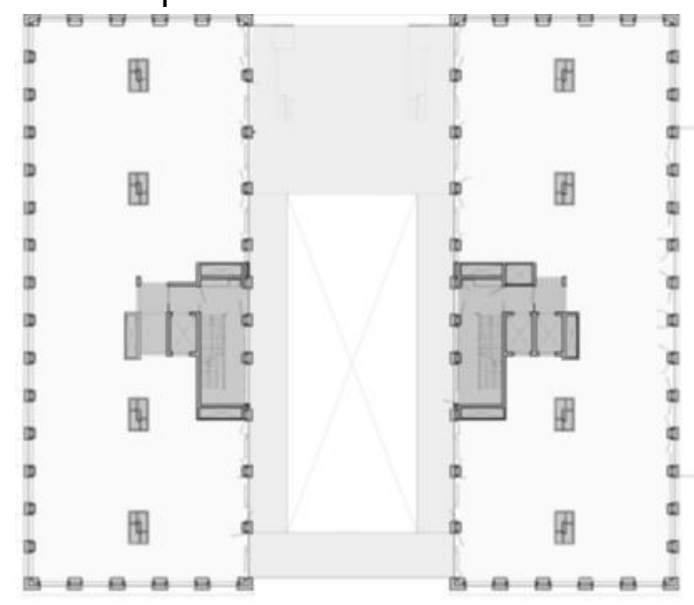

Gambar 5. Solid Tahap Pertama

(Sumber: Archdaily (2002))

Pekerjaan arsitektural tahap pertama terbatas pada perancangan elemen yang umum dan sederhana. Plat lantai ditentukan oleh keliling eksternal, penutup dinding menggunakan material bata sehingga dapat digunakan dengan berbagai kegunaan pada bagian interiornya.
Strukturnya terdiri dari grid kolom 8 meter dan sistem pelat beton ringan pracetak. Hasil akhir dari tahap pertama ini adalah denah terbuka (open plan), pelat lantai yang kosong yang memungkinkan pengguna untuk meletakkan partisi, finishing, dan keperluan lainnya sesuai dengan kebutuhan dan situasi ekonominya.

2. Tahap Kedua

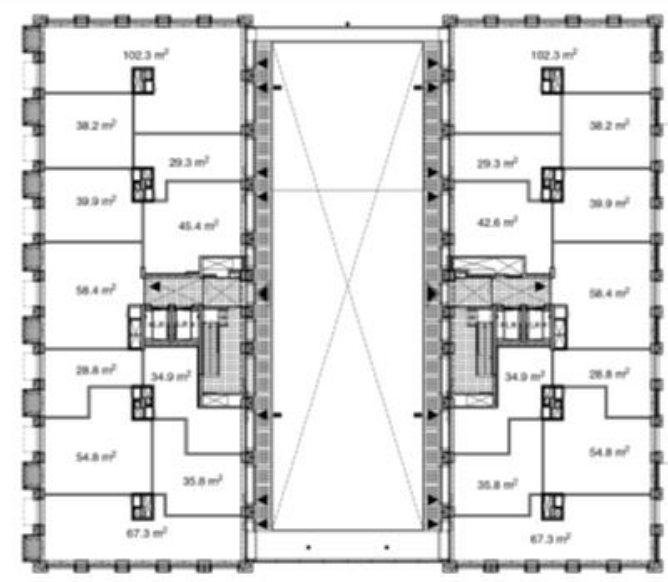

\section{Gambar 6. Solid Tahap Kedua (Sumber: Setien (2015))}

Pada tahap kedua, pembagian ruang dilakukan melalui sistem online, di mana calon penghuni memilih besaran area yang dibutuhkan dan posisi hunian mereka di dalam kompleks. Tujuan utamanya bukan untuk mendapatkan keuntungan, tetapi untuk mendapatkan keseimbangan pencampuran fungsi antara beberapa jenis tipe penghuni (residensial, komersial, dan sosial).

Setelah area spesifik ditetapkan dan partisi dibangun, blok tersebut diserahkan kepada pengguna sebagai 'Shell' atau 'Cangkang'. Cangkang ini dilengkapi dengan insulasi dan dinding pmisah, namun tidak termasuk dengan partisi internal, pintu, kamar mandi, dapur, dan peralatan khusus. Rancangan dan konstruksi interior seluruhnya diserahkan kepada pengguna. 
Disimpulkan, dua tahapan tersebut membuka banyak variasi pilihan kepada pengguna. Pengguna dapat 'menyelesaikan' bloknya saat fase ke dua, mengadaptasikannya ke prefensi dan kemungkinan ekonomi masing-masing. Fase kedua ini dapat diulangi juga di masa depan, setiap pengguna menginginkan perubahan. Jika diinginkan, saat penghuni meninggalkan bloknya, blok tersebut dapat dijual ke tetangganya. Sehingga blok yang ada bisa berkembang (jika digabung dengan blok lain) ataupun mengecil (jika dibagi).

\section{Kesimpulan}

Open building memang bukanlah sistem yang sempurna. Dengan berbagai kekurangan seperti belum ada peraturan dari pemerintah yang mendukung pelaksanaannya, dan belum banyak juga vendor yang mendukung berjalannya sistem yang terbilang baru ini.

Namun sistem open building ini juga ingin mengembalikan hakikat keintiman dari sang pengguna atau penghuni rumah dengan rumah yang mereka tinggali, bagaimana menciptakan rumah yang benar-benar merepresentasikan penghuni sekaligus dapat menunjang dan beradaptasi seiring perubahan kebutuhan yang ada di dalamnya dengan optimal.

Di samping itu juga sistem ini turut mendukung hunian yang berkelanjutan dengan sistem support dan infill yang bukan sebagai suatu kesatuan, sehingga jika ada perbaikan dan perubahan pada bagian infill, bagian support tetap tidak terganggu kestabilannya.

Pada akhirnya sistem ini adalah sistem yang patut dipertimbangkan dalam pembangunan seanjutnya, serta perlunya bantuan dari pemerintah dan pengenalan kepada masyarakat luas jika sistem ini ingin diterapkan.

\section{Daftar Pustaka}

"Solid 11 / Tony Fretton Architects" 15 Feb 2012. ArchDaily. Accessed 23 Dec 2019.

$<$ https://www.archdaily.com/207521/s

olid-11-tony-fretton-architects/> ISSN 0719-8884

Cuperus, Y. (2017). An Introduction to Open Building. OBOM.

Geldermans, B., Tenpierik, M., \& Peter, L. (2019). Circular and Flexible Indoor Partitioning-A Design Conceptualization of Innovative Materials and Value Chains. Buildings.

Habraken, J. N. (2002). The Uses of Levels. Open House International Vol. 27 no. 2.

Kendall, S. (2010). Open Building: An Approach to Sustainable Architecture. Journal of Urban Technology, 6:3, 116.

Kilpatrick, I. (2015). Open Building Architecture and the Importance of Choice \& Independence. reGENERATION - Models for Sustainable Inter-Generational Living.

Li, G., Fan, Y., \& Li, Z. (2015). Open Design for Adaptability in Chinese Public Housing. The Future of Open Building Conference. Zurich: ETH Zürich.

Li, G., Wang, L., \& Li, Y. (2017). A Residential Open Building Roadmap and Potentials in China. UIA 2017 Seoul World Architects Congress. Seoul: UIA.

Nascimento, D. M. (2012). N. J. Habraken Explains the Potential of the Open Building Approach in Architectural Practice. Open House International Vol.37 No.4,, 5-13.

Oorschot, J. A., Durmisevic, E., \& Halman, J. I. (2011). Implementation of Innovation: The Inertia of Implementing the Open Building Concept in Practice. International Conference on Management and Innovation for a Sustainable Built Environment, MISBE (pp. 1-2). 
Amsterdam: Delft University of Technology.

Setien, I. N. (2015). Developments in Residential Open Building: Analysis and Reflections on Two Seminal Case Studies. Perkins \& Will Research Journal Vol. 07.01, 19-35. 